REVIEW ARTICLE

\title{
Review of microsporidia-mosquito relationships: from the simple to the complex
}

\author{
James J. Becnel, Susan E. White and Alexandra M. Shapiro
}

USDA/ARS Center for Medical, Agricultural and Veterinary Entomology, P.O. Box 14565, Gainesville, Florida 32604, USA

Key words: Microsporidia, mosquito, Brachiola algerae, Vavraia culicis, Edhazardia aedis

\begin{abstract}
Microsporidia in mosquitoes can be divided into two categories based on their life cycles and host-parasite relationships. Some species of microsporidia exhibit simple life cycles with one spore type responsible for oral (horizontal) transmission. They affect only one generation of the mosquito and are not usually host or tissue specific. Brachiola algerae (Vavra et Undeen, 1970) and Vavraia culicis (Weiser, 1947) are examples of species isolated from mosquitoes with relatively straightforward life cycles (one spore type) and simple host-parasite relationships. B. algerae and a close relative of $V$. culicis have also been isolated from a vertebrate (human) host but sources for these infections are unknown. In contrast to $B$. algerae and $V$. culicis, polymorphic (heterosporous) microsporidia in mosquitoes are characterized by complex life cycles involving multiple spore types responsible for horizontal and vertical transmission. They affect two generations of the mosquito and some involve an obligate intermediate host. These microsporidia are generally very host and tissue specific with complex develop-mental sequences comprised of unique stages and events. The microsporidium Edhazardia aedis (Kudo, 1930) is a pathogen of Aedes aegypti and does not require an intermediate host. The developmental cycle of $E$. aedis is characterized by four sporulation sequences, two in the parental host and two in the filial generation. Recent speculation relative to the source of $B$. algerae human infection have implicated infected mosquitoes and raised concerns about the safety of mosquito microsporidia in general. The subject of this review is to compare and contrast three species of microsporidia from mosquitoes, two with broad host ranges (B. algerae and $V$. culi$c i s)$ and one specific to mosquitoes (E. aedis). This review describes features that distinguish mosquito-parasitic microsporidia with simple life cycles and broad host ranges from truly mosquito-specific microsporidian parasites with complex life cycles.
\end{abstract}

\section{INTRODUCTION}

Microsporidia that infect mosquitoes have been studied for more than one hundred years on topics ranging from biological control to the effects of microsporidia on the development of human disease-causing organisms in mosquitoes (Becnel and Andreadis 1999). Microsporidia in mosquitoes are excellent model systems for conducting both basic and applied studies. This has led to important contributions to the field of microsporidiology in the areas of taxonomy, developmental cycles and host-pathogen relationships. There are considerable difficulties associated with the study of a complex parasite within a host that cannot be easily manipulated or colonized in the laboratory. Some of these obstacles can be overcome by the study of microsporidia in mosquitoes. First, most mosquitoes have relatively short life cycles (2-3 weeks), are readily manipulated in the laboratory, and many can be easily colonized. In addition, microsporidia are common to mosquitoes and include diverse groups with both simple and complex life cycles. Mosquitoes are also of medical importance as vectors of diseases to man and animals. The study of microsporidia and their mosquito hosts has therefore been extremely productive in resolving many basic questions concerning specific relationships between microsporidia and their hosts as well as resolving fundamental biological events and developmental sequences important to a better overall understanding of the micro-sporidia.

Recently, the mosquito pathogen Brachiola algerae (Vavra et Undeen, 1970) (syn. Nosema algerae) was identified as the cause of fatal myositis in a 57-year-old female patient (Coyle et al. 2004). This has led to speculation relative to the source of this human infection and raised concerns about the safety of mosquito microsporidia in general. The subject of this review is to compare and contrast three species of microsporidia from mosquitoes, two with broad host ranges, B. algerae and Vavraia culicis (Weiser, 1947), and one specific to mosquitoes, Edhazardia aedis (Kudo, 1930).

\section{HISTORY}

One hundred years ago, Hesse (1904) was probably the first researcher to document a true microsporidian

This paper was presented at the NATO Advanced Research Workshop "Emergent Pathogens in the 21st Century: First United Workshop on Microsporidia from Invertebrate and Vertebrate Hosts", held in České Budějovice, Czech Republic, July 12-15, 2004. 
parasite of a mosquito when he described Parathelohania legeri (Hesse, 1904) Codreanu, 1966 from Anopheles maculipennis Meigen. Later, the most comprehensive study of these mosquito parasites at the time was a series of eight publications by Kudo (1921, 1922, 1924a, b, 1925a, b, 1929, 1930) under the general title "Microsporidia Parasitic in Mosquitoes." Kudo (1921) conducted perhaps one of the earliest successful per os transmission experiments producing infections of Culicospora magna (Kudo, 1920) in Culex restuans Theobald by means of a feeding experiment. There was little activity in this area until the discovery of Vavraia culicis (Weiser, 1947) isolated from field populations of Culex pipiens Linnaeus in the Czech Republic. This was notable because subsequent studies with $V$. culicis documented per os transmission to mosquitoes as well as alternate insect hosts indicating this species had a broad host range (Canning 1957, Weiser and Coluzzi 1972, Weiser 1978). The ability to readily transmit $V$. culicis provided only the second opportunity to study in detail a microsporidian pathogen of mosquitoes. This was followed by the discovery and description of Brachiola algerae from a laboratory colony of Anopheles stephensi Liston (Vavra and Undeen 1970). These researchers determined that $B$. algerae was horizontally infectious to mosquito larvae when they were fed spores. Subsequent studies demonstrated that B. algerae had one of the broadest in vivo and in vitro host ranges known, infecting many different orders of insects as well as vertebrate hosts (see Brooks 1988 for a review).

The inability to transmit the "Thelohania-type" microsporidia in mosquitoes (primarily Amblyospora and Parathelohania species) remained an obstacle to lifecycle studies until Kellen and co-workers in the 1960s published a notable series of studies on mosquitomicrosporidia relationships. They described and classified microsporidia in mosquitoes according to tissue specificity and host sex in which the sporogonic cycle occurred in transovarially infected progeny (Kellen and Lipa 1960, Kellen and Wills 1962a, b, Kellen et al. 1966a, b, 1967). This led to the important discovery of spore dimorphism and the role of transovarial transmission in some species of Thelohania (syn. Parathelohania) found parasitizing Anopheles mosquitoes. Hazard and Weiser (1968) reported that a binucleate spore formed in the adult female was responsible for transmitting the pathogen to progeny. Their studies revealed that in infected male larval progeny, uninucleate spores (meiospores) were produced. In infected female progeny, however, spore development was delayed until pupation and adult emergence. In these females, binucleate spores of the original type were produced to repeat the cycle. This represented the first clear documentation of a link between infections in adults and progeny and proved that the two morphologically distinctive spores found in larvae and adult hosts (formerly believed to belong to two genera) represented a single species. While the role of binucleate spores in transovarial transmission continued to be documented, the means by which these microsporidia were transmitted horizontally remained a mystery until the discovery that meiospores formed in larvae were infectious to a copepod intermediate host (Andreadis 1985, Sweeney et al. 1985). When ingested by mosquito larvae, the spores from the copepod intermediate host initiate a sequence of development that ends with binucleate spores in the adult female mosquito. Subsequently, Edhazardia aedis (Kudo, 1930) was described from Aedes aegypti (Linnaeus) with a life cycle comprised of both horizontal and vertical transmission involving two generations of the mosquito but without the involvement of a copepod intermediate host (Becnel et al. 1989). At least four genera, Amblyospora, Hyalinocysta, Duboscqia and Parathelohania, have been documented to require obligatory development in an intermediate copepod host. Detailed studies of these microsporidia have revealed numerous variations on the life cycle that is specialized for each species and host (Hazard and Oldacre 1975, Andreadis 1988, 2002, Sweeney and Becnel 1991, Becnel 1994).

Based on current knowledge, microsporidia in mosquitoes can be divided into two categories based on their life cycles and host-parasite relationships. Some species exhibit simple life cycles with one spore type responsible for oral transmission. They affect only one generation of the mosquito and are not usually host or tissue specific. Brachiola algerae and $V$. culicis are examples of species with one spore type and a simple host-parasite relationship. Other species are characterized by intricate life cycles involving multiple spore types responsible for horizontal and vertical transmission. They affect two generations of the mosquito and some involve an obligate intermediate host. These microsporidia (often termed polymorphic or heterosporous) are generally very host and tissue specific with complex developmental sequences comprised of unique stages and events. Well-studied species with complex life cycles are Amblyospora dyxenoides Sweeney, Graham et Hazard, 1988 (Sweeney et al. 1988), Amblyospora connecticus Andreadis, 1988 (Andreadis 1988), Amblyospora californica (Kellen et Lipa, 1960) (Becnel 1992a), Culicospora magna (Becnel et al. 1987), Hyalinocysta chapmani Hazard et Oldacre, 1975 (Andreadis 2002, Andreadis and Vossbrinck 2002) and E. aedis (Becnel et al. 1989).

\section{MICROSPORIDIA IN MOSQUITOES WITH SIMPLE LIFE CYCLES}

Brachiola algerae (Fig. 1A) was isolated and described from a laboratory colony of A. stephensi by Vavra and Undeen (1970). Only one spore type has been identified (Figs. 2, 3) that is responsible for spread 

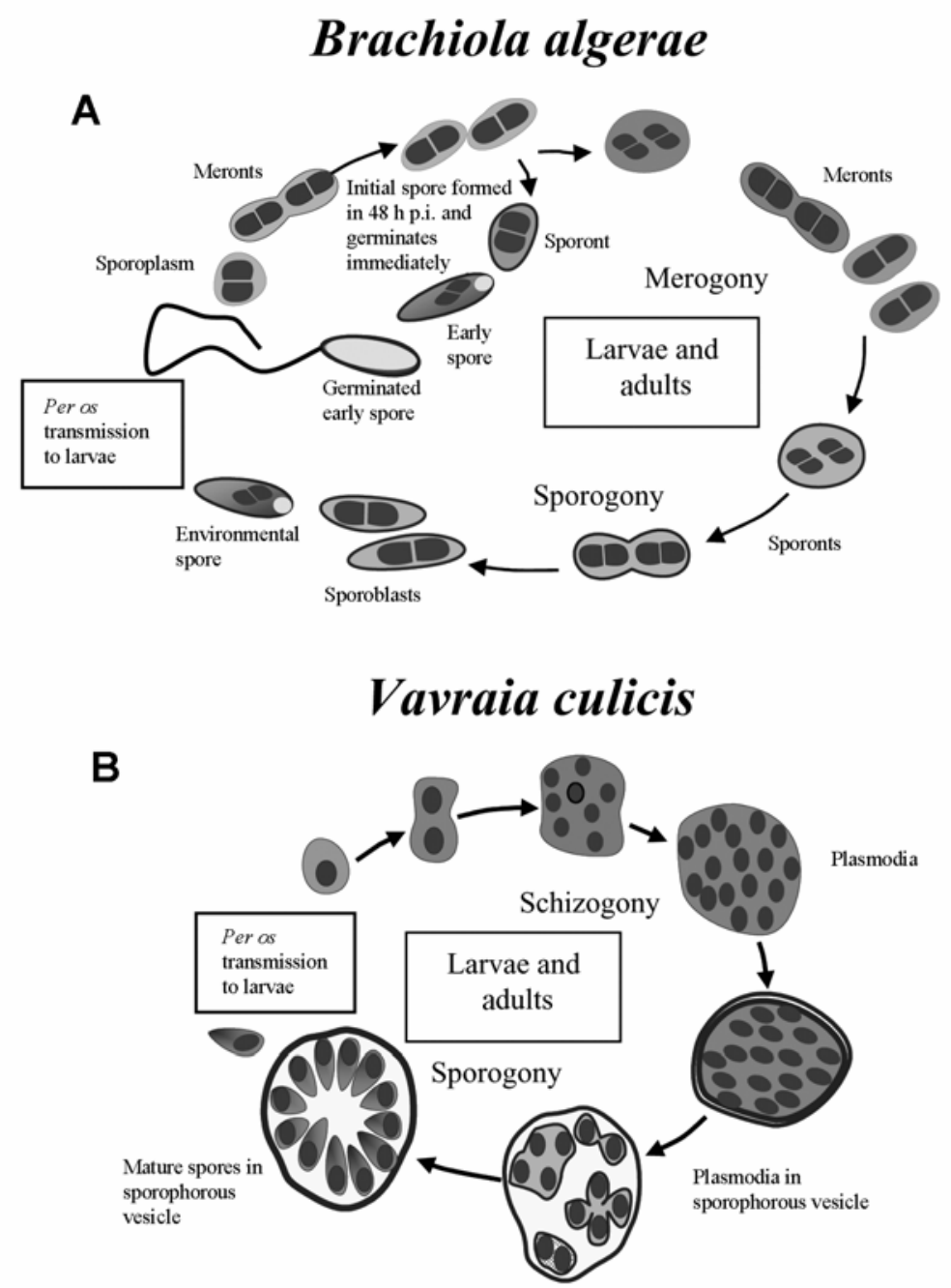

\section{Edhazardia aedis}

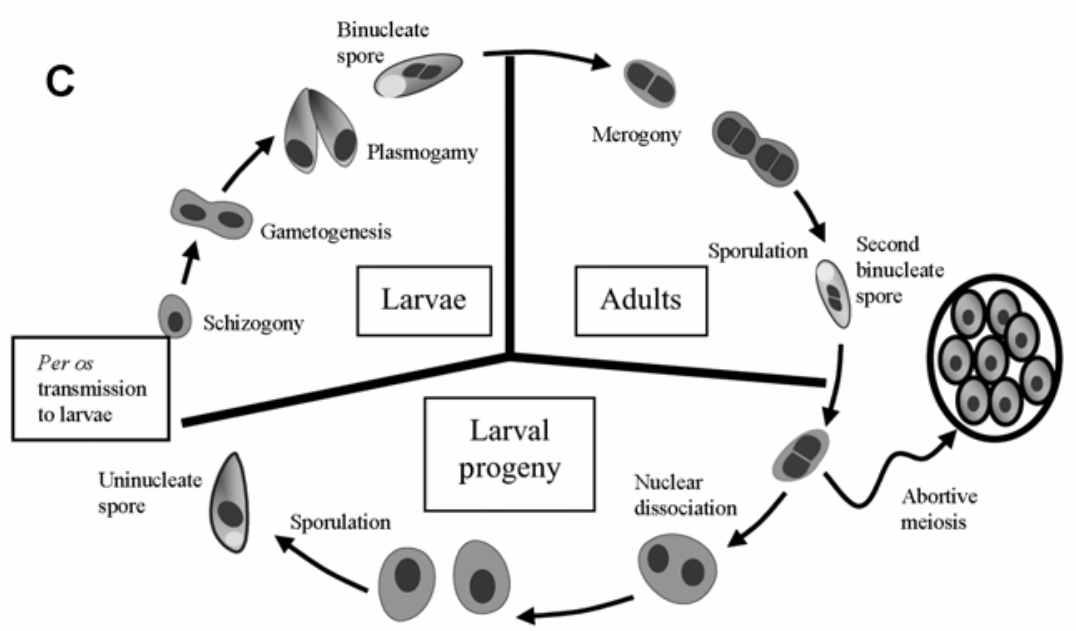

Fig. 1. Schematic representations of the life cycles of mosquito-parasitic microsporidia. A - Brachiola algerae. B - Vavraia culicis. C-Edhazardia aedis. 
within the host (Avery and Anthony 1983) and horizontal (per os) transmission between larval hosts (Vavra and Undeen 1970). All stages are diplokaryotic and in direct contact with the host cell cytoplasm. Developmental stages are covered with electron-dense tubulovesicular secretory materials. Merogony is by binary division of diplokaryotic cells and less frequently by multiple divisions of paucinucleate plasmodia. Diplokaryotic meronts may continue to undergo merogony or may transform into sporonts. Sporogony is disporoblastic with sporonts undergoing one nuclear division to give rise to two diplokaryotic sporoblasts.

Brachiola algerae has been transmitted per os to species from four different orders of insects and one order of trematode (Table 1 and Brooks 1988). It has also been transmitted by injection to species from six orders of insects, a crustacean (Undeen and Maddox 1973) and a mouse (Undeen and Alger 1976). Additional studies conducted with athymic mice injected with $B$. algerae verified development for up to 96 days in the tails (Alger et al. 1980) and up to 49 days in the tail and foot (Trammer et al. 1997). Alger et al. (1980) con-cluded that development of $B$. algerae is limited first by temperature and second by the immune system. Addi-tionally, mice fed upon by adult mosquitoes heavily infected with $B$. algerae were uninfected (Alger et al. 1980). A human, accidentally injected with spores of $B$. algerae, did test positive for antibodies to $B$. algerae; however, a volunteer that allowed infected mosquitoes to bloodfeed on her arm did not test positive for antibodies to B. algerae (Alger et al. 1980). They concluded that $B$. algerae posed no risk to warm-blooded animals. This view has changed dramatically with the first isolation of $B$. algerae from a corneal lesion in an immunocompetent human (Visvesvara et al. 1999). Recently there have been two additional reports from humans, one from a skin lesion in a child with acute lymphatic anaemia (Kucerova et al. 2004) and another from deep muscle in a woman on immunosuppressive drugs (Coyle et al. 2004). This latter report suggested that infection of this patient was the result of crushing an infected mosquito while feeding, thereby mechanically inoculating spores into the skin-bite wound. In studies with a human isolate of B. algerae, intravenous, peroral, or intranasal inoculations failed to establish infections in athymic mice but ocular administration of spores produced severe infection in the liver 60 days post exposure (Koudela et al. 2001). These authors suggested that the physiological conditions in the conjunctiva and cornea served to adapt $B$. algerae to the conditions within the homoiothermic mice.

Without question, $B$. algerae has demonstrated the greatest ability to grow in a wide variety of cells from both invertebrate and vertebrate hosts. This species has been grown in a number of different dipteran and lepi- dopteran cell lines (see Brooks 1988 for an extensive review). Brachiola algerae has also been grown in pig kidney cell cultures but only at temperatures below $37^{\circ} \mathrm{C}$ (Undeen 1975). Recent studies with both mosquito and human isolates of $B$. algerae have demonstrated the ability to grow at $37^{\circ} \mathrm{C}$ in tissue culture but that genera-tion time was extended at the higher temperatures (Trammer et al. 1999, Lowman et al. 2000, Kucerova et al. 2004). It seems clear now that $B$. algerae has the capability to survive and grow at $37^{\circ} \mathrm{C}$ in vitro as well as in vivo.

Vavraia culicis (syn. Pleistophora culicis) is a multisporous species (Fig. 1B) that was described from field populations of Culex pipiens in the Czech Republic (Weiser 1947). All stages are uninucleate with only one spore type that functions to transmit the pathogen between larval hosts (Figs. 4, 5). The earliest stages are uninucleate schizonts with two or more nuclei. A thin electron-dense two-layered coat is secreted on the external surface of the schizont plasmalemma that divides when the plasmodia divide. Repeated nuclear divisions produce plasmodia with up to 16 nuclei. Presporogonic divisions occur by plasmotomy and multiple fission. Sporogony involves plasmodia with commonly 8,16 or 32 nuclei. The surface coat separates from the plasmodium at the onset of sporogony, eventually becoming a sporophorous vesicle. Multiple divisions of lobate plasmodial stages produces 8,16 or 32 uninucleate spores within the sporophorous vesicle (Fukuda et al. 1997).

Vavraia culicis is infectious per os for a wide range of mosquito species with a broad range of susceptibilities (Table 1 and Brooks 1988). In general, Culex and Anopheles spp. are highly susceptible while Aedes spp. are poor hosts. Species from three different families of Lepidoptera are highly susceptible to $V$. culicis and have been used as an alternate system to produce large numbers of spores (Brooks 1988). Extensive host range testing other than in mosquitoes has not been conducted with $V$. culicis but Wang (1982) found that the coleopteran Tenebrio molitor Linnaeus was essentially refractory to infection.

Only a limited number of in vitro studies have been conducted with $V$. culicis but to date only insect cell lines have supported growth. A Mamestra brassicae (Linnaeus) cell line (Smith et al. 1982) and several mosquito ovarian cell lines supported vegetative development and spore production (Wang 1982). There was no detectable development of $V$. culicis in mouse macrophage cells maintained at $37^{\circ} \mathrm{C}$ (Wang 1982).

\section{MICROSPORIDIA IN MOSQUITOES WITH COM- PLEX LIFE CYCLES}

Edhazardia aedis is a highly infectious and virulent parasite of the yellow fever mosquito, A. aegypti (Hembree 1982, Hembree and Ryan 1982). This is a 

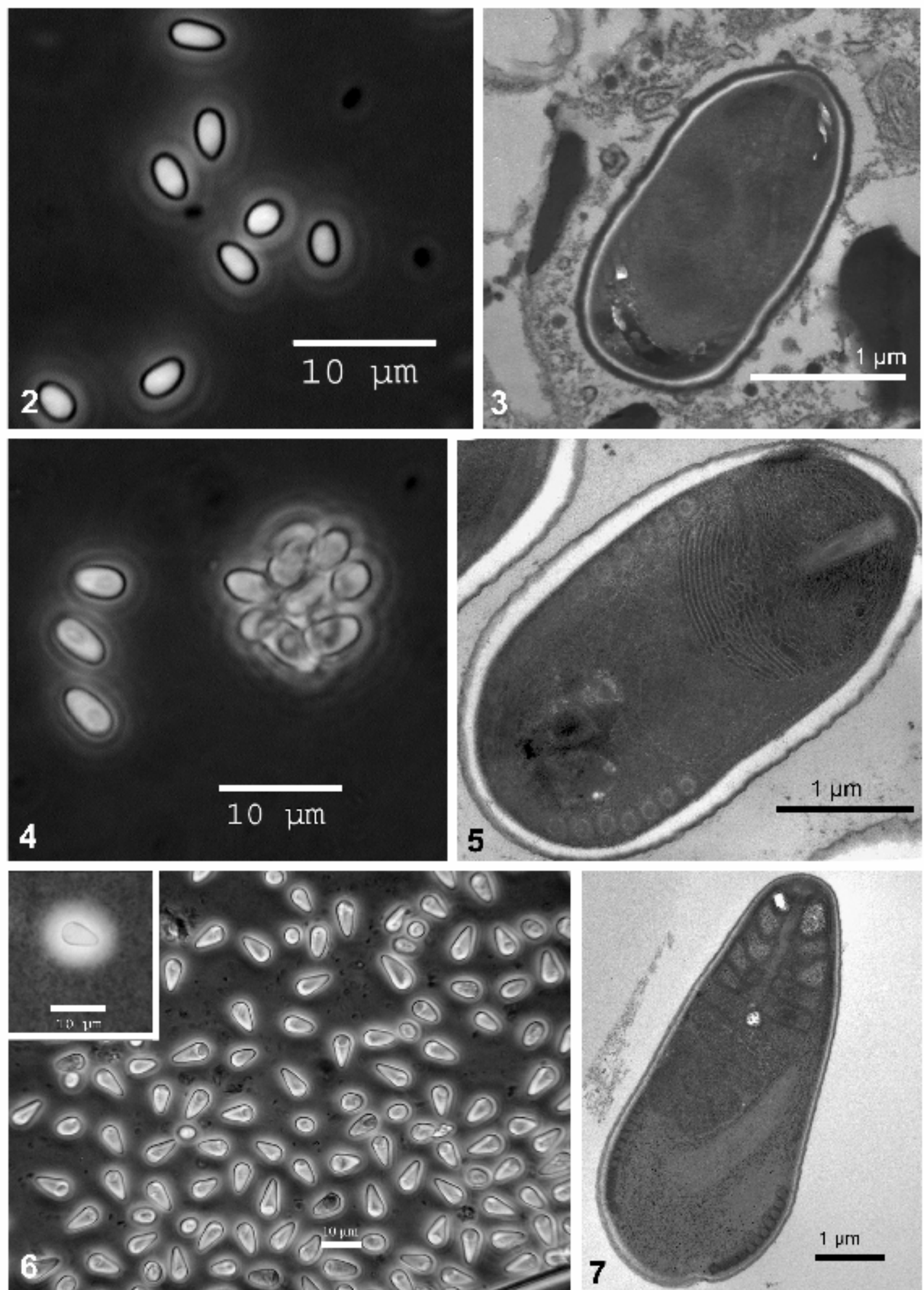

Figs. 2-7. Spores of three mosquito-parasitic microsporidia. Fig. 2. Fresh diplokaryotic spores of Brachiola algerae in India ink preparation. Fig. 3. Transmission electron micrograph of the mature, diplokaryotic spore of Brachiola algerae. Fig. 4. Fresh uninucleate spores of Vavraia culicis in India ink preparation. One group of spores in a sporophorous vesicle. Fig. 5. Transmission electron micrograph of the mature uninucleate spore of Vavraia culicis. Fig. 6. Fresh uninucleate spores of Edhazardia aedis. Inset is a spore in India ink preparation demonstrating a mucous surface coat on the spore. Fig. 7. Transmission electron micrograph of the mature, uninucleate spore of Edhazardia aedis. 
polymorphic (heterosporous) species that has four different sporulation sequences (Fig. $1 \mathrm{C}$ ) and, like $\mathrm{Am}$ blyospora, is both vertically and horizontally transmitted (Andreadis 1988). However, unlike Amblyospora, its life cycle does not involve an intermediate host. Details of its life cycle as characterized by Becnel et al. (1989) and Johnson et al. (1997) are described below.

Edhazardia aedis is horizontally transmitted to larval mosquitoes via oral ingestion of uninucleate-lanceolate spores that are released into the aquatic environment with the death of transovarially infected larvae (Figs. 6, 7 ). Spores readily germinate within the lumen of the midgut and initially infect epithelial cells of the gastric caeca. Here, the microsporidium undergoes a limited asexual multiplicative phase (schizogony) followed by gametogenesis. This results in the formation of uninucle-ate, pyriform gametes that possess a distinctive double-membraned papilla or nipple-like structure on the plasmalemma. Gametes subsequently undergo plasmogamy to form diplokaryotic stages that then develop into small binucleate spores. These primary spores germinate quickly and are responsible for dissemination of $E$. aedis to other host tissues, most significantly the oenocytes. This portion of the life cycle is completed typically within 120 hours of ingestion of the lanceolate spore. Although some variation may occur, most of the mosquito larvae with light to moderate infections develop to adulthood wherein $E$. aedis exhibits a second asexual multiplicative phase (merogony). This takes place within host oenocytes that circulate within the haemocoel and move to areas surrounding the ovaries in female hosts. Sporulation occurs after the female takes a blood meal and this results in the production of a second binucleate spore. This spore, often called the transovarial spore, is responsible for infection of the ovaries and subsequent transmission to the filial generation. In addition to being functionally distinct, the transovarial spore is larger, more oblong, and possesses a longer polar filament and smaller posterior vacuole than the early spore. Infected females exhibit reduced fecundity, longevity (Becnel et al. 1995) and bloodfeeding success (Koella and Agnew 1997).

In larval progeny of the first generation, E. aedis invades fat body tissue and undergoes a third merogony, following which the diplokaryotic phase of the life cycle ends by two different processes, meiosis or nuclear dissociation. The meiotic sequence is similar to that which occurs in Amblyospora but it usually aborts and rarely forms meiospores. In the predominate nuclear dissociation sequence, the two members of the diplokaryon separate and undergo cytokinesis to form two independent haploid cells. These then undergo a sporogonial sequence to form large numbers of uninucleate spores. This process results in death of the larval host and the release of infectious uninucleate spores into the aquatic environment where they may be ingested by other susceptible mosquito larvae to complete the cycle.

Edhazardia aedis is infectious per os to several Aedes spp., Anopheles quadrimaculatus Say, Orthopodomyia signifera (Coquillett) and Toxorhynchites rutilus rutilus (Coquillett) (Table 1) but not species of Culex, Culiseta or Psorophora (Becnel and Johnson 1993, Andreadis 1994). However, E. aedis can not complete its life cycle in these alternate mosquito species as it is not transovarially transmitted to larvae of the filial generation (Becnel and Johnson 1993, Andreadis 1994). $E$. aedis is not infectious for a variety of nontarget aquatic organisms tested (Becnel 1992b). There is no information on the ability of $E$. aedis to grow in cell culture.

\section{DISCUSSION}

Microsporidia that infect immunodeficient humans fall into two main groups: those that are specific parasites of vertebrates and those that are acquired from unknown sources. Recently, two microsporidia with mosquitoes as type definitive hosts $(B$. algerae and $V$. culicis) have been implicated as potential infections in humans. In order to more easily compare these latter species with E. aedis (a representative of the "true" mosquito microsporidia), pertinent features and characteristics are presented in Table 1 . Both $B$. algerae and $V$. culicis have broad host ranges, with $B$. algerae having perhaps the largest know host range for any species of microsporidia. There is a large group of closely related microsporidia in mosquitoes that are very host specific and have complex life cycles (Edhazardia, Amblyo-spora, Parathelohania, etc.). These relationships have been established with classical morphological and life-cycle studies (Becnel 1994) and confirmed with molecu-lar analysis (Vossbrinck et al. 2004a, b). This same molecular analysis has confirmed that $B$. algerae and $V$. culicis are unrelated to this group of "true" microsporidia from mosquitoes and are unrelated to one another. This raises the question as to whether mosquitoes are the natural hosts for $B$. algerae and $V$. culicis (although originally isolated from mosquitoes). In the case of Brachiola, there has recently been another species, Brachiola gambiae Weiser et Žižka, 2004, described from Anopheles gambiae Giles and A. melas Theobald from Liberia (Weiser and Žižka 2004). But questions have been raised about distinctions between the genera Brachiola and Anncaliia as both have Nosema-type life cycles with external tubulovesicular structures on developmental stages that may play a role in the ability of the parasites to grow in a variety of hosts and tissues (Koudela et al. 2001). The two species in the genus Anncaliia (A. meligethi (Issi et Radishcheva, 1979) and A. varivestis (Brooks, Hazard et Becnel, 1985) were isolated from coleopteran hosts and 
Table 1. Features of three mosquito-parasitic microsporidia.

\begin{tabular}{|c|c|c|c|}
\hline $\begin{array}{l}\text { Species } \\
\text { Features }\end{array}$ & $\begin{array}{l}\text { Brachiola algerae } \\
\text { (Illinois isolate) }\end{array}$ & $\begin{array}{l}\text { Vavraia culicis } \\
\text { (Florida isolate) }\end{array}$ & $\begin{array}{l}\text { Edhazardia aedis } \\
\text { (Thailand isolate) }\end{array}$ \\
\hline Original mosquito host & Anopheles stephensi & Aedes albopictus & Aedes aegypti \\
\hline Other mosquito host & $\begin{array}{l}\text { Aedes, Culex, Anopheles, Ar- } \\
\text { migeres, Wyeomyia }\end{array}$ & $\begin{array}{l}\text { Aedes, Culex, Anopheles, } \\
\text { Culiseta }\end{array}$ & $\begin{array}{l}\text { Aedes, Anopheles, Ortho- } \\
\text { podomyia, Toxorhynchites }\end{array}$ \\
\hline $\begin{array}{l}\text { Alternate invertebrate } \\
\text { hosts } \\
\text { (per os or injection) }\end{array}$ & $\begin{array}{l}\text { Per os: Coleoptera, Diptera*, } \\
\text { Hemiptera*, Lepidoptera*, } \\
\text { Digenea } \\
\text { Injection: Decapoda, Mega- } \\
\text { loptera, Odonata, Orthoptera }\end{array}$ & Per os: Diptera, Lepidoptera & None \\
\hline Vertebrate hosts & Rodentia, human isolates & $\begin{array}{l}\text { None, close to Trachipleisto- } \\
\text { phora hominis }\end{array}$ & None \\
\hline Cell lines & Invertebrate and vertebrate & Invertebrate & None \\
\hline Nuclear arrangement & Diplokaryotic & Unikaryotic & $\begin{array}{r}\text { Unikaryotic and } \\
\text { diplokaryotic }\end{array}$ \\
\hline Tissues infected & Systemic (can vary with host) & Systemic & Midgut, oenocytes, fat body \\
\hline Life cycle & One-host, larvae and adults & One-host, larvae & One-host, larvae and adults \\
\hline Vertical transmission & Transovum & No & Transovarial \\
\hline Molecular relationship & Brachiola clade & Pleistophora, Vavraia clade & Amblyospora clade \\
\hline
\end{tabular}

*Also infected by injection.

in the case of $V$. varivestis, it is capable of infecting some other beetle species and a lepidopteran host (Brooks et al. 1985). If members of these two genera also have broad host ranges similar to $B$. algerae, sources for possible human infections by this group would probably extend beyond mosquitoes.

Vavraia culicis has not been isolated from a vertebrate host but molecular data indicate a close relationship with the human pathogen Trachipleistophora homi-nis Hollister, Canning, Weidner, Field, Kench et Mar-riott, 1996 and $V$. oncoperae (Milner et Beaton, 1977) from a lepidopteran host; this cluster also contains the fish microsporidium Pleistophora typicalis Gurley, 1893 (Cheney et al. 2000). Athymic mice were infected with $T$. hominis when inoculated orally, intraperitoneally or with itramuscular injections. V. culicis and several species of Pleistophora from fish were inoculated into athymic mice with intramuscular injections but infec-tions were not established. T. hominis also infected several species of mosquitoes when spores were fed to larvae (Weidner et al. 1999). This led to speculation that there are microsporidian species in biting flies that may be the source for infections found in immunodeficient humans (Cheney et al. 2000). Given that $V$. culicis readily infects a number of lepidopteran hosts and that a close relative $V$. oncoperae was isolated from a lepidopteran, it seems reasonable to expand the possible sources for Trachipleistophora infections in man to other insects.

\section{CONCLUSIONS AND FUTURE DIRECTIONS}

Microsporidia in mosquitoes have served well as model systems for understanding complex host-parasite relationships, life cycles, developmental cycles as well as addressing taxonomic issues. Studies on mosquitoes led to the discovery of dimorphism for the microsporidia and documented that a single species of microsporidia can possess two morphologically and functionally distinct spore types (Hazard and Weiser 1968). To date, the only intermediate host systems for microsporidia have been determined for species of $\mathrm{Am}$ blyospora (10 species) (Andreadis 1985, 1999, Sweeney et al. 1985, 1990, Becnel 1992a, White et al. 1994, Becnel and Andreadis 1998, Micieli et al. 1998, 2000a, b,), Para-thelohania (1 species) (Avery and Undeen 1990), Duboscqia (1 species) (Sweeney et al. 1993) and Hya-linocysta (1 species) (Andreadis 2002) from mosquito hosts; all of these require an obligate copepod intermediate host to complete the life cycle. Studies on this latter group of genera have also been instrumental in understanding polymorphism in microsporidia and the role of morphologically and functionally distinctive spore types. Knowledge on developmental and sexual sequences for microsporidia has been greatly influenced by studies in mosquitoes with the identification of gametes and the formation of diplokarya and mechanisms for haplosis by either meiosis or nuclear dissociation (Becnel 1994). With respect to 
taxonomy, recent molecular phylogenetic analyses of the small subunit rDNA sequences of mosquitoparasitic microsporidia (Baker et al. 1998, Vossbrinck et al. 1998, 2004a, b) confirm the relatedness of the "true" mosquito microsporidia and suggest that mosquitoes and their parasites have co-evolved. Finally, $B$. algerae and $V$. culicis isolated from and studied in mosquitoes has provided crucial foundational information that have become highly relevant to studies of microsporidia in vertebrates and specifically man (Vavra and Undeen 1970, Undeen 1975, Undeen and Alger 1976).

If the accomplishments during the past 100 years are indicative of future success, then the study of microsporidia in mosquitoes promises to contribute significantly to both invertebrate and vertebrate microsporidiology. For the "true" mosquito microsporidia, new groups with complex life cycles will continue to reveal variations and new pathways with a better understanding of the basic mechanisms for host exploitation. For B. algerae, $V$. culicis and related forms with broad host ranges, comparative studies utilizing the mosquito and human isolates should provide additional clues for resolving the epidemiology of vertebrate and human microsporidia transmission. It is truly an exciting time for studies on mosquito-parasitic microsporidia with high expectations for the next 100 years.

Acknowledgements. We thank Dr. Graham White (University of Florida) and Dr. Christopher Geden (USDA/ARS) for con-structive comments and editorial remarks on an earlier version of the manuscript.

\section{REFERENCES}

ALGER N.E., MADDOX J.V., SHADDUCK J.A. 1980: Nosema algerae: infectivity and immune response in normal and nude mice. WHO/VBC/80.778.7.

ANDREADIS T.G. 1985: Experimental transmission of a microsporidian pathogen from mosquitoes to an alternate copepod host. Proc. Natl. Acad. Sci. U.S.A. 82: 5574 5577.

ANDREADIS T.G. 1988: Amblyospora connecticus sp. nov. (Microsporida: Amblyosporidae): horizontal transmission studies in the mosquito Aedes cantator and formal description. J. Invertebr. Pathol. 52: 90-101.

ANDREADIS T.G. 1994: Host range tests with Edhazardia aedis (Microsporida: Culicosporidae) against northern Nearctic mosquitoes. J. Invertebr. Pathol. 64: 46-51.

ANDREADIS T.G. 1999: Epizootiology of Amblyospora stimuli (Microsporida: Amblyosporidae) infections in field populations of a univoltine mosquito, Aedes stimulans (Diptera: Culicidae), inhabiting a temporary vernal pool. J. Invertebr. Pathol. 74: 198-205.

ANDREADIS T.G. 2002: Epizootiology of Hyalinocysta chapmani (Microsporidia: Thelohaniidae) infections in field populations of Culiseta melanura (Diptera: Culicidae) and Orthocyclops modestus (Copepoda: Cyclopidae): a three-year investigation. J. Invertebr. Pathol. 81: 114121.

ANDREADIS T.G., VOSSBRINCK C.R. 2002: Life cycle, ultrastructure and molecular phylogeny of Hyalinocysta chapmani (Microsporidia: Thelohaniidae), a parasite of Culiseta melanura (Diptera: Culicidae) and Orthocyclops modestus (Copepoda: Cyclopidae). J. Eukaryot. Microbiol. 49: 350-364.

AVERY S.W., ANTHONY D.W. 1983: Ultrastructural study of early development of Nosema algerae in Anopheles albimanus. J. Invertebr. Pathol. 42: 87-95.

AVERY S.W., UNDEEN A.H. 1990: Horizontal transmission of Parathelohania anophelis to the copepod, Microcyclops varicans, and the mosquito, Anopheles quadrimaculatus. J. Invertebr. Pathol. 56: 98-105.
BAKER M.D., VOSSBRINCK C.R., BECNEL J.J., ANDREADIS T.G. 1998: Phylogeny of Amblyospora (Microsporida: Amblyosporidae) and related genera based on small subunit ribosomal DNA data: a possible example of host parasite cospeciation. J. Invertebr. Pathol. 71: 199206.

BECNEL J.J. 1992a: Horizontal transmission and subsequent development of Amblyospora californica (Microsporida: Amblyosporidae) in the intermediate and definitive hosts. Dis. Aquat. Org. 13: 17-28.

BECNEL J.J. 1992b: Safety of Edhazardia aedis (Microspora: Amblyosporidae) for nontarget aquatic organisms. J. Am. Mosq. Control Assoc. 8: 256-260.

BECNEL J.J. 1994: Life cycles and host-parasite relationships of microsporidia in culicine mosquitoes. Folia Parasitol. 41: 91-96.

BECNEL J.J., ANDREADIS T.G. 1998: Amblyospora salinaria $\mathrm{n}$. sp. (Microsporidia: Amblyosporidae), parasite of Culex salinarius (Diptera: Culicidae): its life cycle stages in an intermediate host. J. Invertebr. Pathol. 71: 258-262.

BECNEL J.J., ANDREADIS T.G. 1999: Microsporidia in insects. In M. Wittner (Ed.), The Microsporidia and Microsporidiosis. ASM Press, Washington, DC, pp. 447501.

BECNEL J.J., GARCIA J.J., JOHNSON M.A. 1995: Edhazardia aedis (Microspora: Culicosporidae) effects on the reproductive capacity of Aedes aegypti (Diptera: Culicidae). J. Med. Entomol. 32: 549-553.

BECNEL J.J., HAZARD E.I., FUKUDA T., SPRAGUE V. 1987: Life cycle of Culicospora magna (Kudo, 1920) (Microsporida: Culicosporidae) in Culex restuans Theobald with special reference to sexuality. J. Protozool. 34: 313-322.

BECNEL J.J., JOHNSON M.A. 1993: Mosquito host range and specificity of Edhazardia aedis (Microspora: Culicosporidae). J. Am. Mosq. Control Assoc. 9: 269-274.

BECNEL J.J., SPRAGUE V., FUKUDA T., HAZARD E.I. 1989: Development of Edhazardia aedis (Kudo, 1930) 
n. g., n. comb. (Microsporida: Amblyosporidae) in the mosquito Aedes aegypti (L.) (Diptera: Culicidae). J. Protozool. 36: 119-130.

BROOKS W.M. 1988: Entomogenous Protozoa. In C.M. Ignoffo and N.B. Mandava (Eds.), CRC Handbook of Natural Pesticides, Vol. 5, Microbial Insecticides, Part A, Entomogenous Protozoa and Fungi. CRC Press, Boca Raton, pp. 1-149.

BROOKS W.M., HAZARD E.I., BECNEL J.J. 1985: Two new species of Nosema (Microsporida: Nosematidae) from the Mexican bean beetle Epilachna varivestis (Coleoptera: Coccinellidae). J. Protozool. 32: 525-535.

CANNING E.U. 1957: Plistophora culicis Weiser (Protozoa, Microsporidia): its development in Anopheles gambiae. Trans. R. Soc. Trop. Med. Hyg. 51: 8.

CHENEY S.A., LAFRANCHI-TRISTEM N.J., CANNING E.U. 2000: Phylogenetic relationships of Pleistophora-like microsporidia based on small subunit ribosomal DNA sequences and implications for the source of Trachipleistophora hominis infections. J. Eukaryot. Microbiol. 47: 280-287.

COYLE C.M., WEISS L.M., RHODES L.V. 3rd, CALI A., TAKVORIAN P.M., BROWN D.F., VISVESVARA G.S., XIAO L., NAKTIN J., YOUNG E., GARECA M., COLASANTE G., WITTNER M. 2004: Fatal myositis due to the microsporidian Brachiola algerae, a mosquito pathogen. N. Engl. J. Med. 351: 42-47.

FUKUDA T., WILLIS O.R., BARNARD D.R. 1997: Parasites of the Asian tiger mosquito and other container-inhabiting mosquitoes (Diptera: Culicidae) in northcentral Florida. J. Med. Entomol. 34: 226-233.

HAZARD E.I., OLDACRE S.W. 1975: Revision of Microsporidia (Protozoa) close to Thelohania, with descriptions of one new family, eight new genera and thirteen new species. U. S. Dept. Agric. Tech. Bull. No. 1530, 104 pp.

HAZARD E.I., WEISER J. 1968: Spores of Thelohania in adult female Anopheles: development and transovarial transmission, and redescriptions of $T$. legeri Hesse and $T$. obesa Kudo. J. Protozool. 15: 817-823.

HEMBREE S.C. 1982: Dose-response studies of a new species of per os and vertically transmittable microsporid-ian pathogen of Aedes aegypti from Thailand. Mosq. News 42: $55-61$.

HEMBREE S.C., RYAN J.R. 1982: Observations on the vertical transmission of a new microsporidian pathogen of Aedes aegypti from Thailand. Mosq. News 42: 49-54.

HESSE E. 1904: Thelohania legeri n. sp., microsporidie nouvelle, parasite des larves d'Anopheles maculipennis Meig. C. R. Soc. Biol. 57: 570-571.

JOHNSON M.A., BECNEL J.J., UNDEEN A.H. 1997: A new sporulation sequence in Edhazardia aedis (Microsporidia: Culicosporidae), a parasite of the mosquito Aedes aegypti (Diptera: Culicidae). J. Invertebr. Pathol. 70: 69-75.

KELLEN W.R., CHAPMAN H.C., CLARK T.B., LINDEGREN J.E. 1966a: Transovarian transmission of some Thelohania (Nosematidae: Microsporidia) in mosquitoes of California and Louisiana. J. Invertebr. Pathol. 8: 355359.

KELLEN W.R., CLARK T.B., LINDEGREN J.E. 1967: Two previously undescribed Nosema from mosquitoes of Cali- fornia (Nosematidae: Microsporidia). J. Invertebr. Pathol. 9: 19-25.

KELLEN W.R., CLARK T.B., LINDEGREN J.E., SANDERS R.D. 1966b: Development of Thelohania californica in two hybrid mosquitoes. Exp. Parasitol. 18: 251-254.

KELLEN W.R., LIPA J. 1960: Thelohania californica n. sp., a microsporidian parasite of Culex tarsalis Coquillett. J. Insect Pathol. 2: 1-12.

KELLEN W.R., WILLS W. 1962a: New Thelohania from Californian mosquitoes (Nosematidae: Microsporidia). J. Insect Pathol. 4: 41-56.

KELLEN W.R., WILLS W. 1962b: The transovarian transmission of Thelohania californica Kellen and Lipa in Culex tarsalis Coquillett. J. Insect Pathol. 4: 321-326.

KOELLA J.C., AGNEW P. 1997: Blood-feeding success of the mosquito Aedes aegypti depends on the transmission route of its parasite Edhazardia aedis. Oikos 78: 311-316.

KOUDELA B., VISVESVARA G.S., MOURA H., VÁVRA J. 2001: The human isolate of Brachiola algerae (Phylum Microspora): development in SCID mice and description of its fine structure features. Parasitology 123: 153-162 .

KUCEROVA Z., MOURA H., VISVESVARA G.S., LEITCH G.J. 2004: Differences between Brachiola (Nosema) algerae isolates of human and insect origin when tested using an in vitro spore germination assay and a cultured cell infection assay. J. Eukaryot. Microbiol. 51: 339-343.

KUDO R. 1920: Cnidosporidia in the vicinity of Urbana. Trans. Ill. State. Acad. Sci. 13: 298-303.

KUDO R. 1921: Studies on microsporidia with special reference to those parasitic in mosquitoes. J. Morphol. 35: 153-193.

KUDO R. 1922: Studies on microsporidia parasitic in mosquitoes. II. On the effect of the parasites upon the host body. J. Parasitol. 8: 70-77.

KUDO R. 1924a: Studies on microsporidia parasitic in mosquitoes. III. On Thelohania legeri Hesse (=Th. illinoisensis Kudo). Arch. Protistenkd. 49: 147-162.

KUDO R. 1924b: Studies on microsporidia parasitic in mosquitoes. VI. On the development of Thelohania opacita, a culicine parasite. J. Parasitol. 11: 84-89.

KUDO R. 1925a: Studies on microsporidia parasitic in mosquitoes. IV. Observations upon the microsporidia found in the mosquitoes of Georgia, USA. Zentralbl. Bakteriol. Parasitenkd. Infektionskr. Hyg. Abt. 1, Orig. 96: 428-440.

KUDO R. 1925b: Studies on microsporidia parasitic in mosquitoes. V. Further observations upon Stempellia (Thelohania) magna Kudo, parasitic in Culex pipiens and C. territans. Biol. Bull. 48: 112-127.

KUDO R. 1929: Studies on microsporidia parasitic in mosquitoes. VII. Notes on microsporidia of some Indian mosquitoes. Arch. Protistenkd. 67: 1-10.

KUDO R. 1930: Studies on microsporidia parasitic in mosquitoes. VIII. On a microsporidan, Nosema aedis nov. spec., parasitic in a larva of Aedes aegypti of Porto Rico. Arch. Protistenkd. 69: 23-38.

LOWMAN P.M., TAKVORIAN P.M., CALI A. 2000: The effects of elevated temperatures and various time-temperature combinations on the development of Brachiola (Nosema) algerae $\mathrm{n}$. comb. in mammalian cell culture. J. Eukaryot. Microbiol. 47: 221-234. 
MICIELI M.V., GARCIA J.J., BECNEL J.J. 1998: Horizontal transmission of Amblyospora dolosi (Microsporidia: Amblyosporidae) to the copepod Metacyclops mendocinus (Wierzejski, 1892). J. Invertebr. Pathol. 72 : 330-335.

MICIELI M.V., GARCIA J.J., BECNEL J.J. 2000a: Horizontal transmission of Amblyospora albifasciati Garcia and Becnel, 1994 (Microsporidia: Amblyosporidae), to a copepod intermediate host and the neotropical mosquito, Aedes albifasciatus (Macquart, 1837). J. Invertebr. Pathol. 75: 76-83.

MICIELI M.V., GARCIA J.J., BECNEL J.J. 2000b: Life cycle and description of Amblyospora camposi n. sp (Microspo-ridia: Amblyosporidae) in the mosquito Culex renatoi (Diptera, Culicidae) and the copepod Paracyclops fimbriatus fimbriatus (Copepoda, Cyclopidae). J. Eukaryot. Microbiol. 47: 575-580.

SMITH J.E., BARKER R.J., LAI P.F. 1982: Culture of microsporidia from invertebrates in vertebrate cells. Parasitology 85: 427-435.

SWEENEY A.W., BECNEL J.J. 1991: Potential of microsporidia for the biological control of mosquitoes. Parasitol. Today 7: 217-220.

SWEENEY A.W., DOGGETT S.L., PIPER R.G. 1990: Life cycle of Amblyospora indicola (Microspora: Amblyosporidae), a parasite of the mosquito Culex sitiens and of Apocyclops sp. copepods. J. Invertebr. Pathol. 55: 428434.

SWEENEY A.W., DOGGETT S.L., PIPER R.G. 1993: Life cycle of a new species of Duboscqia (Microsporida: Thelohaniidae) infecting the mosquito Anopheles hilli and an intermediate copepod host, Apocyclops dengizicus. J. Invertebr. Pathol. 62: 137-146.

SWEENEY A.W., GRAHAM M.F., HAZARD E.I. 1988: Life cycle of Amblyospora dyxenoides sp. nov. in the mosquito Culex annulirostris and the copepod Mesocyclops albicans. J. Invertebr. Pathol. 51: 46-57.

SWEENEY A.W., HAZARD E.I., GRAHAM M.F. 1985: Intermediate host for an Amblyospora sp. (Microspora) infecting the mosquito, Culex annulirostris. J. Invertebr. Pathol. 46: 98-102.

TRAMMER T., CHIORALIA G., MAIER W.A., SEITZ H.M. 1999: In vitro replication of Nosema algerae (Microsporidia), a parasite of anopheline mosquitoes, in human cells above 36 degrees C. J. Eukaryot. Microbiol. 46: 464 468.

TRAMMER T., DOMBROWSKI F., DOEHRING M., MAIER W.A., SEITZ H.M. 1997: Opportunistic properties of Nosema algerae (Microspora), a mosquito parasite, in immunocompromised mice. J. Eukaryot. Microbiol. 44: 258-262.

UNDEEN A.H. 1975: Growth of Nosema algerae in pig kidney cell cultures. J. Protozool. 22: 107-110.

UNDEEN A.H., ALGER N.E. 1976: Nosema algerae: infection of the white mouse by a mosquito parasite. Exp. Parasitol. 40: 86-88.
UNDEEN A.H., MADDOX J.V. 1973: The infection of nonmosquito hosts by injection with spores of the microsporidian Nosema algerae. J. Invertebr. Pathol. 22: 258265.

VAVRA J., UNDEEN A.H. 1970: Nosema algerae n. sp. (Cnidospora, Microsporida) a pathogen in a laboratory colony of Anopheles stephensi Liston (Diptera: Culicidae). J. Protozool. 17: 240-249.

VISVESVARA G.S., BELLOSO M., MOURA H., DA SILVA A.J., MOURA I.N., LEITCH G.J., SCHWARTZ D.A., CHEVEZ-BARRIOS P., WALLACE S., PIENIAZEK N.J., GOOSEY J.D. 1999: Isolation of Nosema algerae from the cornea of an immunocompetent patient. J. Eukaryot. Microbiol. 46: 10S.

VOSSBRINCK C.R., ANDREADIS T.G., DEBRUNNERVOSSBRINCK B.A. 1998: Verification of intermediate hosts in the life cycles of microsporidia by small subunit rDNA sequencing. J. Eukaryot. Microbiol. 45: 290-292.

VOSSBRINCK C.R., ANDREADIS T.G., VAVRA J., BECNEL J.J. 2004a: Molecular phylogeny and evolution of mosquito parasitic microsporidia (Microsporidia: Amblyosporidae). J. Eukaryot. Microbiol. 51: 88-95.

VOSSBRINCK C.R., ANDREADIS T.G., VAVRA J., BECNEL J.J. 2004b: Molecular phylogeny and evolution of mosquito parasitic microsporidia (Microsporidia: Amblyosporidae) (errata). J. Eukaryot. Microbiol. 51: 259261.

WANG B. 1982: The pathobiology of the mosquito parasite, Vavraia culicis (Weiser). Ph.D. Thesis, University of California, Los Angeles, $151 \mathrm{pp}$.

WEIDNER E., CANNING E.U., RUTLEDGE C.R., MEEK C.L. 1999: Mosquito (Diptera: Culicidae) host compatibility and vector competency for the human myositic parasite Trachipleistophora hominis (Phylum Microspora). J. Med. Entomol. 36: 522-525.

WEISER J. 1947: Klíč k určování Mikrosporidií. Acta Soc. Sci. Nat. Moravicae 18: 1-64.

WEISER J. 1978: Production of the microsporidian Plistophora culicis Weiser in substitute host. Folia Parasitol. 25: 365.

WEISER J., COLUZZI M. 1972: The microsporidian Plistophora culicis Weiser, 1946 in different mosquito hosts. Folia Parasitol. 19: 197-202.

WEISER J., ŽIŽKA Z. 2004: Brachiola gambiae sp. n. the microsporidian parasite of Anopheles gambiae and A melas in Liberia. Acta Protozool. 43: 73-80.

WHITE S.E., FUKUDA T., UNDEEN A.H. 1994: Horizontal transmission of Amblyospora opacita (Microspora: Amblyosporidae) between the mosquito, Culex territans, and the copepod, Paracyclops fimbriatus chiltoni. J. Invertebr. Pathol. 63: 19-25. 